Correspondence

Hidetoshi Morita morita@azabu-u.ac.jp

\title{
Sharpea azabuensis gen. nov., sp. nov., a Gram- positive, strictly anaerobic bacterium isolated from the faeces of thoroughbred horses
}

Hidetoshi Morita, ${ }^{1}$ Chiharu Shiratori, ${ }^{1}$ Masaru Murakami, ${ }^{1}$ Hideto Takami, ${ }^{2}$ Hidehiro Toh, ${ }^{3}$ Yukio Kato, ${ }^{1}$ Fumihiko Nakajima, ${ }^{4}$ Misako Takagi, ${ }^{5}$ Hiroaki Akita, ${ }^{4}$ Toshio Masaoka ${ }^{1}$ and Masahira Hattori ${ }^{6}$

\author{
${ }^{1}$ School of Veterinary Medicine, Azabu University, 1-17-71 Fuchinobe, Sagamihara, Kanagawa \\ 229-8501, Japan \\ ${ }^{2}$ Microbial Genome Research Group, Japan Agency of Marine-Earth Science and Technology, 2-15 \\ Natsushima, Yokosuka, Kanagawa 237-0061, Japan \\ ${ }^{3}$ RIKEN Genomic Sciences Center, 1-7-22 Suehiro, Tsurumi, Yokohama, Kanagawa 230-0045, \\ Japan \\ ${ }^{4}$ Northern Farm, 275 Hayakita-genbu, Abira-cho, Yufutsu-gun, Hokkaido 059-1432, Japan \\ ${ }^{5}$ Clossfield-Bio Inc., 1-1-20 Higashi-nihonbashi, Chuo-ku, Tokyo 103-0004, Japan \\ ${ }^{6}$ Graduate School of Frontier Sciences, University of Tokyo, 5-1-5 Kashiwanoha, Kashiwa, Chiba \\ 277-8562, Japan
}

\begin{abstract}
Four bacterial strains, designated $\mathrm{ST} 18^{\top}, \mathrm{HM} 244, \mathrm{HM} 250$ and DI49, were isolated from the fresh faeces of four thoroughbred horses in Japan. Cells were Gram-positive, strictly anaerobic, catalase-negative, non-spore-forming, non-motile rods that occurred in chains. They were placed in the same subcluster based on 16S rRNA gene sequence analysis, phenotypic characteristics and levels of DNA-DNA relatedness. Their DNA $G+C$ content ranged from 36 to $38 \mathrm{~mol} \%$. Lactobacillus catenaformis, Lactobacillus vitulinus and Catenibacterium mitsuokai belong to cluster XVII of the Clostridium subphylum. Strain $\mathrm{ST} 18^{\top}$ was most closely related to $L$. catenaformis ATCC $25536^{\top}$ in the phylogenetic tree, but these strains shared only $89.9 \%$ (1336/ 1486 bp) $16 \mathrm{~S}$ rRNA gene sequence similarity. L. catenaformis, L. vitulinus and C. mitsuokai are homofermentative bacteria, whereas $\mathrm{ST} 18^{\top}$ produced $\mathrm{CO}_{2}$ from glucose. Whereas the cell-wall peptidoglycan type of $L$. catenaformis and $L$. vitulinus was $L-L y s-L-A l a_{3}$, that of $C$. mitsuokai and the subgroup represented by ST $18^{\top}$ was A1 $\gamma$ (L-Ala-D-Glu-meso-diaminopimelic acid). On the basis of $16 \mathrm{~S}$ rRNA gene sequence divergence of more than $10 \%$ from $L$. catenaformis as well as phenotypic characteristics, strains ST18 ${ }^{\top}, \mathrm{HM} 244, \mathrm{HM} 250$ and DI49 are considered to represent a novel species of a new genus belonging to the Clostridium subphylum cluster XVII, for which the name Sharpea azabuensis gen. nov., sp. nov. is proposed. The type strain of Sharpea azabuensis is $\mathrm{ST}^{\mathrm{T}} 8^{\top}\left(=\mathrm{JCM} 14210^{\top}=\mathrm{DSM} 18934^{\top}\right)$.
\end{abstract}

Various Gram-positive, non-spore-forming, rod-shaped anaerobic bacteria belonging to the Clostridium subphylum

Abbreviation: $m$-Dpm, meso-diaminopimelic acid.

The GenBank/EMBL/DDBJ accession numbers for the $16 \mathrm{~S}$ rRNA gene sequences of strains ST18 $, \mathrm{HM} 244, \mathrm{HM} 250$ and DI49 and Lactobacillus vitulinus JCM $1143^{\top}$ are AB210824, AB360599, AB360600, AB360601 and AB210825, respectively.

Maximum-parsimony and maximum-likelihood phylogenetic trees and tables detailing the sources of strain isolation and levels of DNA-DNA relatedness are available as supplementary material with the online version of this paper. make up the predominant intestinal microflora in mammals. Some genera of the Clostridium subphylum have been inadequately described (Collins et al., 1994; Kageyama \& Benno, 2000a, b; Willems \& Collins, 1996; Willems et al., 1996) and, because of their broad definitions, these genera have acted as a depository for a large number of phylogenetically diverse species. For example, some species originally assigned to the genus Eubacterium in the Clostridium subphylum have subsequently been transferred to other genera or to new genera (Kageyama et al., 1999a, b; Ludwig et al., 1992; Nakazawa et al., 2000; Taras et al., 2002; Wade et al., 1999; Willems 
\& Collins, 1996). The clusters of the Clostridium subphylum provide a useful starting point for investigations of phylogenetic relationships among the Gram-positive, nonspore-forming, rod-shaped anaerobic bacteria of the mammalian intestinal tract. The genus Lactobacillus belongs to the phylum Firmicutes, class Bacilli, order Lactobacillales, family Lactobacillaceae, and its closest relatives, grouped within the same family, are members of the genera Paralactobacillus and Pediococcus (Garrity et al., 2007). Lactobacillus vitulinus and Lactobacillus catenaformis are related only distantly to other recognized Lactobacillus species (Hammes \& Vogel, 1995; Hammes \& Hertel, 2006; Pot et al., 1994; Schleifer \& Ludwig, 1996), given that they belong to cluster XVII of the Clostridium subphylum rather than to the Lactobacillales (Collins et al., 1994).

In the present study, four bacterial strains (designated $\mathrm{ST} 18^{\mathrm{T}}$, HM244, HM250 and DI49) were isolated from the faeces of four thoroughbred horses. A polyphasic taxonomic study of these strains was performed based on phenotypic characterization and phylogenetic as well as genetic methods. The results obtained suggest that these four strains represent a single novel species of a new genus belonging to cluster XVII of the Clostridium subphylum.

Fresh faeces of four thoroughbred horses were collected from two stables and one farm in Japan (for details see Supplementary Table S1 in IJSEM Online). The faecal specimens were transferred to the laboratory within $24 \mathrm{~h}$ under anaerobic conditions by use of an AnaeroPak (Mitsubishi Gas Chemical) at $4{ }^{\circ} \mathrm{C}$. A diluent containing $0.85 \% \mathrm{NaCl}, 0.05 \%$ sodium pyruvate and $0.05 \%$ sodium ascorbate was used. Dissolved oxygen was removed by bubbling the solution with nitrogen gas for $60 \mathrm{~min}$. Initial processing and subsequent weighing and dilution of the specimens were carried out under anaerobic conditions. Each dilution was then spread on blood liver (BL) agar plates (Eiken Chemical Co.) containing $0.05 \%$ sodium pyruvate and $0.05 \%$ sodium ascorbate and incubated anaerobically at $37{ }^{\circ} \mathrm{C}$ for 2 days. All further cultivation was performed at $37{ }^{\circ} \mathrm{C}$ in anaerobic bacterial culture medium (ABCM) broth (Eiken Chemical Co.). L. catenaformis JCM $1121^{\mathrm{T}}$, L. vitulinus JCM $1143^{\mathrm{T}}$ and Catenibacterium mitsuokai JCM $10609^{\mathrm{T}}$, belonging to the Clostridium subphylum cluster XVII, were obtained from the Japan Collection of Microorganisms (JCM).

Approximately 1500 bp of the 16S rRNA gene sequences of 137 isolates were determined by using standard primers (27F, 520F, 930F, 1100F, 75R, 520R, 800R and 1100R) (Weisburg et al., 1991; Miyake et al., 1998) via an ABI PRISM 3100 Genetic Analyzer (Applied Biosystems). More than $99 \% 16 \mathrm{~S}$ rRNA gene sequence similarity was observed (approximately $1500 \mathrm{bp}$ ) among strains ST18 ${ }^{\mathrm{T}}$, HM244, HM250 and DI49 (see Supplementary Table S1 for accession numbers). The $\mathrm{G}+\mathrm{C}$ content of the DNA was determined by enzymically hydrolysing the DNA and quantifying the nucleosides by using HPLC based on the method proposed by Ezaki et al. (1990). The DNA G+C contents of the four novel strains ranged from 36.8 to $37.9 \mathrm{~mol} \%$. Fluorometric DNA-DNA hybridization was carried out in microdilution wells according to the method proposed by Ezaki et al. (1989). DNA-DNA hybridization analyses were performed among the four strains, and levels of relatedness between strain ST18 ${ }^{\mathrm{T}}$ and strains HM244, HM250 and DI49 were 81.8, 93.1 and $89.2 \%$, respectively. These values are above the $70 \%$ cut-off recommended for the delineation of separate bacterial species (Stackebrandt \& Goebel, 1994), indicating that the four novel strains represented the same genomic species.

The closest known relatives of the isolates were determined by performing sequence similarity database researches. Multiple alignments of the sequences were carried out by using CLUSTAL W (Thompson et al., 1994). The robustness of individual branches was estimated by using a bootstrap analysis of 1000 replicates (Felsenstein, 1985). Phylogenetic trees were constructed by using the neighbour-joining (Saitou \& Nei, 1987), maximum-likelihood (Cavalli-Sforza \& Edwards, 1967) and maximum-parsimony (Kluge \& Farris, 1969) methods within PHYLIP version 3.66 (Felsenstein, 2005). In the neighbour-joining dendrogram created based on $16 \mathrm{~S}$ rRNA gene sequences, strain ST18 ${ }^{\mathrm{T}}$ was placed within the unique $L$. vitulinus phylogenetic group (Felis \& Dellaglio, 2007) and was related closely to $L$. catenaformis, L. vitulinus and Catenibacterium mitsuokai (Fig. 1). Similar phylogenetic trees were obtained with the maximum-likelihood and maximum-parsimony methods (Supplementary Figs S1 and S2). The 16S rRNA gene sequence of strain $\mathrm{ST} 18^{\mathrm{T}}$ showed $89.9 \%(1336 / 1486 \mathrm{bp})$ similarity to that of L. catenaformis ATCC $25536^{\mathrm{T}}$. The physiological characteristics of strain $\mathrm{ST}_{1} 8^{\mathrm{T}}$ were thus compared with those of $L$. catenaformis JCM $1121^{\mathrm{T}}, L$. vitulinus JCM $1143^{\mathrm{T}}$ and Catenibacterium mitsuokai JCM $10609^{\mathrm{T}}$ (Table 1).

The DNA G + C content of strain $\mathrm{ST} 18^{\mathrm{T}}$ was $37.4 \mathrm{~mol} \%$, higher than the values obtained for $L$. catenaformis JCM $1121^{\mathrm{T}}$ (34.8 mol\%), L. vitulinus JCM $1143^{\mathrm{T}}$ (34.4 mol\%) and Catenibacterium mitsuokai JCM $10609^{\mathrm{T}}$ (36.6 mol\%). Carbohydrate fermentation patterns were determined by using a test medium that comprised $10 \mathrm{~g}$ peptone (Becton, Dickinson; $\mathrm{BD}), 10 \mathrm{~g}$ trypeptone (BD), $3 \mathrm{~g}$ soy peptone (BD), $2.5 \mathrm{~g}$ potassium dihydrogen phosphate (Nacalai tesque), 3 g meat extract (BD), $2 \mathrm{~g} \mathrm{NaCl}$ (Nacalai tesque), $0.3 \mathrm{~g}$ L-cysteine hydrochloride (Nacalai tesque), $0.005 \mathrm{~g}$ haemin (Nacalai tesque), $0.3 \mathrm{~g}$ sodium thioglycolate (Nacalai tesque), $0.17 \mathrm{~g}$ bromocresol purple (Nacalai tesque), and glucose, galactose, fructose, mannose, cellobiose, lactose, salicin, melibiose, trehalose, raffinose, starch, D-arabinose, D-ribose, D-xylose, rhamnose, mannitol, sorbitol or melezitose (all at $10 \mathrm{~g} \mathrm{l}^{-1}$; Nacalai tesque) as carbohydrates at $\mathrm{pH}$ 6.8. The results were recorded after $48 \mathrm{~h}$ at $37^{\circ} \mathrm{C}$ under anaerobic conditions. Strain ST $18^{\mathrm{T}}$ fermented and produced acid from glucose, galactose, fructose, mannose, cellobiose, lactose, melibiose and starch. However, as some of the novel strains were able to ferment 


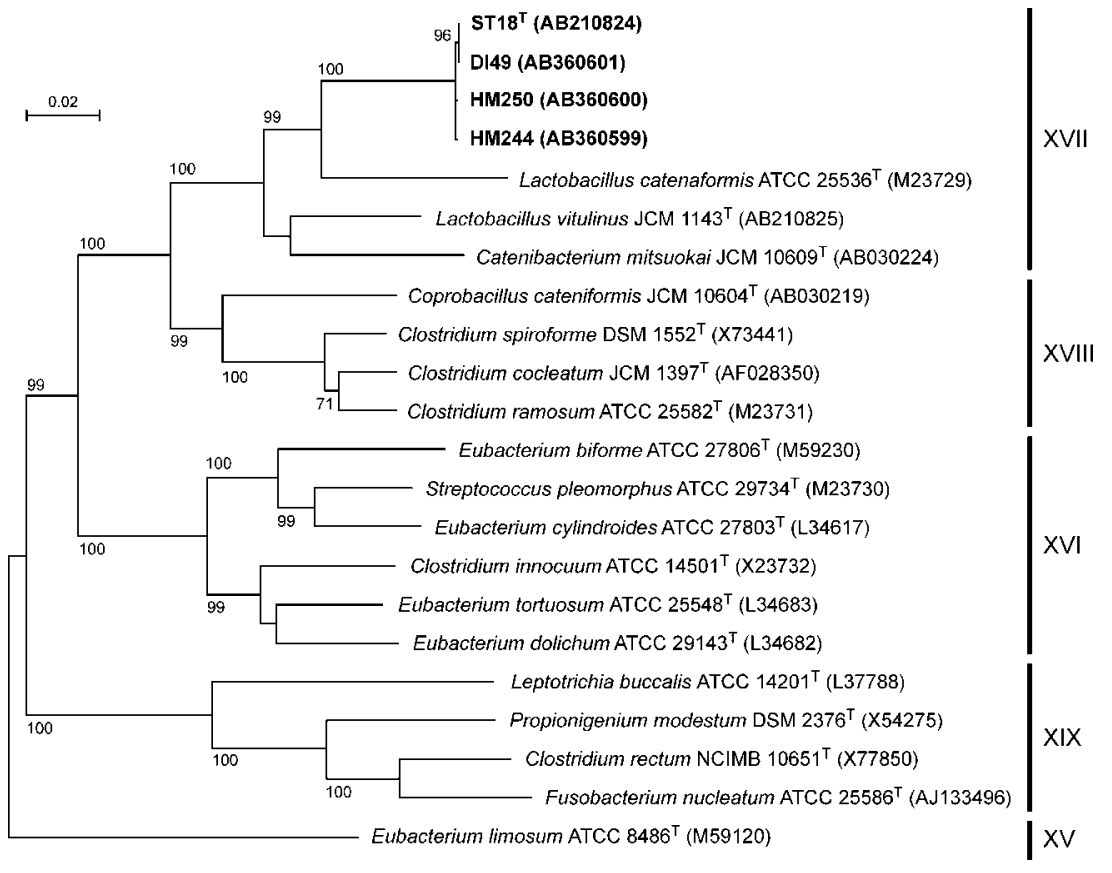

Fig. 1. Phylogenetic relationships between strains ST18 ${ }^{\mathrm{T}}$, HM244, HM250 and DI49 and species in clusters XV-XIX of the Clostridium subphylum based on 16S rRNA gene sequences. The tree was constructed by using the neighbour-joining method. Bootstrap values above $70 \%$ are indicated at branch points. Eubacterium limosum ATCC $8486^{\top}$ was used as an outgroup. Bar, 0.02 substitutions per nucleotide position. salicin, trehalose and raffinose, it was difficult to distinguish this subcluster from $L$. catenaformis, L. vitulinus and Catenibacterium mitsuokai based on carbohydrate fermentation patterns (Table 1). The isomer of lactic acid produced from glucose was determined by using a
D/L-lactic acid F-kit (Roche Diagnostics). Strain ST18 ${ }^{\mathrm{T}}$ and the three other faecal strains produced only $\mathrm{D}(-)$-lactic acid. Other biochemical tests, such as those relating to motility, growth at a fixed temperature and gas production from glucose, were performed by using the methods

Table 1. Physiological characteristics of strains $\mathrm{ST}_{18}{ }^{\top}, \mathrm{HM} 244, \mathrm{HM} 250$ and $\mathrm{D} / 49$ and related type strains

Reference strains: 1, L. catenaformis JCM $1121^{\mathrm{T}}$ (data from this study); 2, L. vitulinus JCM $1143^{\mathrm{T}}$ (data from Sharpe et al., 1973); 3, Catenibacterium mitsuokai JCM $10609^{\mathrm{T}}$ (data from Kageyama \& Benno, 2000a). +, Positive; -, negative; w, weakly positive; ND, no data available. All strains were positive for the fermentation of glucose, galactose, fructose, mannose, cellobiose and lactose. All strains were negative for aerobic growth, growth at $15{ }^{\circ} \mathrm{C}$, catalase activity and fermentation of rhamnose, mannitol, sorbitol and melezitose. DNA G $+\mathrm{C}$ contents were determined by HPLC.

\begin{tabular}{|c|c|c|c|c|c|c|c|}
\hline Characteristic & ST18 ${ }^{\mathrm{T}}$ & HM244 & HM250 & DI49 & 1 & 2 & 3 \\
\hline Lactic acid isomer(s) & $\mathrm{D}$ & $\mathrm{D}$ & $\mathrm{D}$ & $\mathrm{D}$ & $\mathrm{D}$ & $\mathrm{D}$ & DL \\
\hline Gas production from glucose & + & + & + & + & - & - & - \\
\hline Fermentation style ${ }^{\star}$ & $\mathrm{HE}$ & $\mathrm{HE}$ & $\mathrm{HE}$ & $\mathrm{HE}$ & $\mathrm{HO}$ & $\mathrm{HO}$ & $\mathrm{HO}$ \\
\hline \multicolumn{8}{|l|}{ Fermentation of: } \\
\hline Salicin & - & + & + & - & + & + & + \\
\hline Melibiose & + & + & + & + & - & + & $\mathrm{ND}$ \\
\hline Trehalose & - & + & + & - & - & - & - \\
\hline Raffinose & - & + & + & + & - & - & - \\
\hline Starch & + & $\mathrm{w}$ & + & + & + & + & - \\
\hline D-Xylose & - & - & - & - & + & - & - \\
\hline D-Arabinose & - & - & - & - & + & - & - \\
\hline D-Ribose & - & - & - & - & + & - & - \\
\hline DNA G $+\mathrm{C}$ content $(\mathrm{mol} \%)$ & 37.4 & 37.9 & 36.8 & 37.4 & 34.8 & 34.4 & 36.6 \\
\hline Peptidoglycan type & $\begin{array}{l}\text { Al } \gamma(\mathrm{L}-\mathrm{Ala}-\mathrm{D}- \\
\text { Glu- } m \text {-Dpm })\end{array}$ & $\begin{array}{l}\text { Al } \gamma(\mathrm{L}-\mathrm{Ala}-\mathrm{D}- \\
\text { Glu- } m-\mathrm{Dpm})\end{array}$ & $\begin{array}{l}\text { Al } \gamma(\mathrm{L}-\mathrm{Ala}-\mathrm{D}- \\
\text { Glu- } m-\mathrm{Dpm})\end{array}$ & $\begin{array}{l}\text { Al } \gamma(\mathrm{L}-\mathrm{Ala}-\mathrm{D}- \\
\text { Glu- } m \text {-Dpm) }\end{array}$ & $\begin{array}{l}\text { L-Lys-L- } \\
\mathrm{Ala}_{3}\end{array}$ & $\begin{array}{l}\text { L-Lys-L- } \\
\mathrm{Ala}_{3}\end{array}$ & $\begin{array}{l}\text { Al } \gamma(\mathrm{L}-\mathrm{Ala}-\mathrm{D}- \\
\text { Glu- } m \text {-Dpm })\end{array}$ \\
\hline
\end{tabular}

${ }^{\star} \mathrm{HE}$, Heterofermentative; HO, homofermentative. 
described by Mitsuoka (1969). Table 1 details the characteristics most useful in distinguishing the strains studied from closely related bacteria. As strain $\mathrm{ST} 18^{\mathrm{T}}$ and the other three novel strains produced gas $\left(\mathrm{CO}_{2}\right)$ from glucose, this phenomenon clearly distinguished them from L. catenaformis, L. vitulinus and Catenibacterium mitsuokai.

DNA-DNA hybridization analyses were performed between strain $\mathrm{ST} 18^{\mathrm{T}}$, L. catenaformis $\mathrm{JCM} 1121^{\mathrm{T}}, L$. vitulinus JCM $1143^{\mathrm{T}}$ and Catenibacterium mitsuokai JCM $10609^{\mathrm{T}}$. Levels of relatedness were less than the $70 \%$ cutoff point recommended for the delineation of species (Stackebrandt \& Goebel, 1994) (Supplementary Table S2). Based on the methods proposed by Komagata \& Suzuki (1987), meso-diaminopimelic acid ( $m$-Dpm) was found in the peptidoglycan layer of the subgroup represented by strain ST $18^{\mathrm{T}}$ by using HPLC. The cell-wall peptidoglycan of strain $\mathrm{ST} 18^{\mathrm{T}}$ contained $m$-Dpm, glutamic acid and alanine at a molar ratio of $1: 1: 2$, as determined by ultrahigh-performance liquid chromatography. The structural type was A1 $\gamma$ (L-Ala-D-Glu-m-Dpm). Strains HM244, HM250 and DI49 possessed the same peptidoglycan type (as did Catenibacterium mitsuokai). In contrast, the cellwall peptidoglycan type of $L$. catenaformis and $L$. vitulinus was L-Lys-L-Ala ${ }_{3}$.

The four novel strains isolated from the faeces of thoroughbred horses clearly belonged to a hitherto unrecognized, Gram-positive anaerobic species within the Clostridium subphylum cluster XVII. Based on $16 \mathrm{~S}$ rRNA gene sequence comparisons, the bacterium has a close phylogenetic relationship with $L$. catenaformis, $L$. vitulinus and Catenibacterium mitsuokai. Although the association between these taxa was significant (Supplementary Table S1), a 16S rRNA gene sequence divergence of more than $10 \%$ suggested that this relationship was one of phylogenetically closely related but different genera. On the basis of 165 rRNA gene sequence considerations and other phenotypic characteristics, these strains merit classification within a novel species of a new genus, for which the name Sharpea azabuensis gen. nov., sp. nov. is proposed.

\section{Description of Sharpea gen. nov.}

Sharpea (Shar.pe'a. N.L. fem. n. Sharpea named in honour of Michaela E. Sharpe, for her considerable efforts in the development of evolutionary microbiology).

Cells occur in short chains and spores are absent. Grampositive, strictly anaerobic and heterofermentative bacteria. The cell wall contains $m$-Dpm, glutamic acid and alanine, and the peptidoglycan type is Al $\gamma$ (L-Ala-D-Glu-m-Dpm). The G $+C$ content of the DNA of known strains is 36.8$37.9 \mathrm{~mol} \%$. The genus Sharpea is a member of cluster XVII of the Clostridium subphylum of Gram-positive bacteria and exhibits a close phylogenetic association with Lactobacillus catenaformis, Lactobacillus vitulinus and Catenibacterium mitsuokai. The type species is Sharpea azabuensis.

\section{Description of Sharpea azabuensis sp. nov.}

Sharpea azabuensis (a.za.bu.en'sis. N.L. fem. adj. azabuensis arbitrary name referring to the fact that the study in which the species was described was supported by the Azabu 'Academic Frontier' Project for Private Universities: Matching Fund Subsidy).

Cells are catalase-negative, non-motile rods $(2-10 \mu \mathrm{m}$ long and $0.7-1.0 \mu \mathrm{m}$ wide). When grown on $\mathrm{BL}$ agar at $37^{\circ} \mathrm{C}$ for $24 \mathrm{~h}$, colonies are $1.0-2.5 \mathrm{~mm}$, circular to slightly irregular, with undulating edges, flat in elevation, smooth, brown, transparent and butyrous. The optimum growth temperature is $37^{\circ} \mathrm{C}$. Unable to grow under aerobic conditions, in the presence of $4.5 \% \mathrm{NaCl}$ or at $15{ }^{\circ} \mathrm{C}$, but grows in the presence of $3 \% \mathrm{NaCl}$ and at $45{ }^{\circ} \mathrm{C}$. Metabolizes glucose heterofermentatively, and produces $\mathrm{D}(-)$-lactic acid and $\mathrm{CO}_{2}$. Acids are produced by the type strain from glucose, galactose, fructose, mannose, cellobiose, lactose, melibiose and starch. Some strains can ferment salicin, trehalose and raffinose. Unable to ferment rhamnose, mannitol, sorbitol or melezitose.

The type strain, ST18 ${ }^{\mathrm{T}}\left(=\mathrm{JCM} 14210^{\mathrm{T}}=\mathrm{DSM} 18934^{\mathrm{T}}\right)$, was isolated from the faeces of a thoroughbred horse. HM244, HM250 and DI49, also isolated from faeces of thoroughbred horses, are additional strains of the species.

\section{Acknowledgements}

We are grateful to the Ikee and Seishi stables of the Japan Racing Association and Keisuke Shimamura of the KK Bestsellers for sampling horse faeces. This work was supported by the Azabu Academic Frontier Project: Matching Fund Subsidy for Private Universities, 2002-2006.

\section{References}

Cavalli-Sforza, L. L. \& Edwards, A. W. F. (1967). Phylogenetic analysis models and estimation procedures. Am J Hum Genet 19, 233-257.

Collins, M. D., Lawson, P. A., Willems, A., Cordoba, J. J., FernandezGarayzabal, J., Garcia, P., Cai, J., Hippe, H. \& Farrow, J. A. E. (1994). The phylogeny of the genus Clostridium: proposal of five new genera and eleven new species combinations. Int J Syst Bacteriol 44, 812-826.

Ezaki, T., Hashimoto, Y. \& Yabuuchi, E. (1989). Fluorometric deoxyribonucleic acid-deoxyribonucleic acid hybridization in microdilution wells as an alternative to membrane filter hybridization in which radioisotopes are used to determine genetic relatedness among bacterial strains. Int J Syst Bacteriol 39, 224-229.

Ezaki, T., Saidi, S. M., Liu, S.-L., Hashimoto, Y., Yamamoto, H. \& Yabuuchi, E. (1990). Rapid procedure to determine the DNA base composition from small amounts of Gram-positive bacteria. FEMS Microbiol Lett 67, 127-130.

Felis, G. E. \& Dellaglio, F. (2007). Taxonomy of lactobacilli and bifidobacteria. Curr Issues Intest Microbiol 8, 44-61.

Felsenstein, J. (1985). Confidence limits on phylogenies: an approach using the bootstrap. Evolution 39, 783-791.

Felsenstein, J. (2005). PHYLIP (phylogeny inference package), version 3.65. Distributed by the author. Department of Genome Sciences, University of Washington, Seattle, USA. 
Garrity, G. M., Lilburn, T. G., Cole, J. R., Harrison, S. H., Euzéby, J. \& Tindall, B. J. (2007). The Taxonomic Outline of Bacteria and Archaea. Release 7.7. http://www.taxonomicoutline.org/index.php/toba/index

Hammes, W. P. \& Hertel, C. (2006). The genera Lactobacillus and Carnobacterium. In The Prokaryotes: a Handbook on the Biology of Bacteria, 3rd edn, vol. 4, pp. 320-403. Edited by M. Dworkin, S. Falkow, E. Rosenberg, K. H. Schleifer \& E. Stackebrandt. New York: Springer.

Hammes, W. P. \& Vogel, R. F. (1995). The genus Lactobacillus. In The Lactic Acid Bacteria, the Genera of Lactic Acid Bacteria, vol. 2, pp. 1954. Edited by B. J. B. Wood \& W. H. Holzapfel. London: Blackie Academic \& Professional.

Kageyama, A. \& Benno, Y. (2000a). Catenibacterium mitsuokai gen. nov., sp. nov., a Gram-positive anaerobic bacterium isolated from human faeces. Int J Syst Evol Microbiol 50, 1595-1599.

Kageyama, A. \& Benno, Y. (2000b). Emendation of genus Collinsella and proposal of Collinsella stercoris sp. nov. and Collinsella intestinalis sp. nov. Int J Syst Evol Microbiol 50, 1767-1774.

Kageyama, A., Benno, Y. \& Nakase, T. (1999a). Phylogenic and phenotypic evidence for the transfer of Eubacterium fossor to the genus Atopobium as Atopobium fossor comb. nov. Microbiol Immunol 43, 389-395.

Kageyama, A., Benno, Y. \& Nakase, T. (1999b). Phylogenetic and phenotypic evidence for the transfer of Eubacterium aerofaciens to the genus Collinsella as Collinsella aerofaciens gen. nov., comb. nov. Int $J$ Syst Bacteriol 49, 557-565.

Kluge, A. G. \& Farris, F. S. (1969). Quantitative phyletics and the evolution of anurans. Syst Zool 18, 1-32.

Komagata, K. \& Suzuki, K. (1987). Lipid and cell-wall analysis in bacterial systematics. Methods Microbiol 19, 161-207.

Ludwig, W., Kirchhof, G., Weizenegger, M. \& Weiss, N. (1992). Phylogenetic evidence for the transfer of Eubacterium suis to the genus Actinomyces as Actinomyces suis comb. nov. Int J Syst Bacteriol 42, 161-165.

Mitsuoka, T. (1969). Vergleichende Untersuchungen uber die Lactobazillen aus den Faeces von Menschen, Schweinen und Huhnern. Zentralbl Bakteriol [Orig] 210, 32-51 (in German).

Miyake, T., Watanabe, K., Watanabe, T. \& Oyaizu, H. (1998). Phylogenetic analysis of the genus Bifidobacterium and related genera based on 16S rDNA sequences. Microbiol Immunol 42, 661-667.

Nakazawa, F., Sato, M., Poco, S. E., Hashimura, T., Ikeda, T., Kalfas, S., Sundqvist, G. \& Hoshino, E. (2000). Description of Mogibacterium pumilum gen. nov., sp. nov. and Mogibacterium vescum gen. nov., sp. nov., and reclassification of Eubacterium timidum (Holdeman et al. 1980 ) as Mogibacterium timidum gen. nov., comb. nov. Int J Syst Evol Microbiol 50, 679-688.
Pot, B., Ludwig, W., Kersters, K. \& Schleifer, K. H. (1994). Taxonomy of lactic acid bacteria. In Bacteriocins of Lactic Acid Bacteria: Microbiology, Genetics and Applications, pp. 13-90. Edited by L. De Vuyst \& E. J. Vandamme. London: Blackie Academic \& Professional.

Saitou, N. \& Nei, M. (1987). The neighbor-joining method: a new method for reconstructing phylogenetic trees. Mol Biol Evol 4, 406425.

Schleifer, K. H. \& Ludwig, W. (1996). Phylogeny of the genus Lactobacillus and related genera. Syst Appl Microbiol 18, 461-467.

Sharpe, M. E., Latham, M. J., Garvie, E. I., Zirngibl, J. \& Kandler, O. (1973). Two new species of Lactobacillus isolated from the bovine rumen, Lactobacillus ruminis sp. nov. and Lactobacillus vitulinus sp. nov. J Gen Microbiol 77, 37-49.

Stackebrandt, E. \& Goebel, B. M. (1994). Taxonomic note: a place for DNA-DNA reassociation and $16 \mathrm{~S}$ rRNA sequence analysis in the present species definition in bacteriology. Int J Syst Bacteriol 44, 846849.

Taras, D., Simmering, R., Collins, M. D., Lawson, P. A. \& Blaut, M. (2002). Reclassification of Eubacterium formicigenerans Holdeman and Moore 1974 as Dorea formicigenerans gen. nov., comb. nov., and description of Dorea longicatena sp. nov., isolated from human faeces. Int J Syst Evol Microbiol 52, 423-428.

Thompson, J. D., Higgins, D. G. \& Gibson, T. J. (1994). CLUSTAL W: improving the sensitivity of progressive multiple sequence alignment through sequence weighting, position-specific gap penalties and weight matrix choice. Nucleic Acids Res 22, 4673-4680.

Wade, W. G., Downes, J., Dymock, D., Himon, S. J., Weightman, A. J., Dewhirst, F. E., Paster, B. J., Tzellas, N. \& Coleman, B. (1999). The family Coriobacteriaceae: reclassification of Eubacterium exiguum (Poco et al. 1996) and Peptostreptococcus heliotrinreducens (Lanigan 1976) as Slackia exigua gen. nov., comb. nov. and Slackia heliotrinireducens gen. nov., comb. nov., and Eubacterium lentum (Prevot 1938) as Eggerthella lenta gen. nov., comb. nov. Int J Syst Bacteriol 49, 595-600.

Weisburg, W. G., Barns, S. M., Pelletier, D. A. \& Lane, D. J. (1991). $16 \mathrm{~S}$ ribosomal DNA amplification for phylogenetic study. J Bacteriol 173, 697-703.

Willems, A. \& Collins, M. D. (1996). Phylogenetic relationships of the genera Acetobacterium and Eubacterium sensu stricto and reclassification of Eubacterium alactolyticum as Pseudoramibacter alactolyticus gen. nov., comb. nov. Int J Syst Bacteriol 46, 1083-1087.

Willems, A., Amat-Marco, M. \& Collins, M. D. (1996). Phylogenetic analysis of Butyrivibrio strains reveals three distinct groups of species within the Clostridium subphylum of the Gram-positive bacteria. Int $J$ Syst Bacteriol 46, 195-199. 